\title{
Mutsuz eden yöneticilerden beklenen liderlik tarzları üzerine senaryo araştırması
}

\author{
Ali Murat ALPARSLAN ${ }^{1}$, Funda KIRAN ${ }^{2}$, Şükriye KILIÇ AKSOY ${ }^{3}$, Dorukcan PEHLIVAN ${ }^{4}$ \\ ${ }^{1}$ Doç. Dr./ Burdur Mehmet Akif Ersoy Üniversitesi / İktisadi ve İdari Bilimler Fakültesi / İşletme Bölümü/ alimurat@mehmetakif.edu.tr Orcid: 0000-0002-1682- \\ 4202 \\ ${ }^{2}$ Arş. Gör./ Burdur Mehmet Akif Ersoy Üniversitesi / Bucak Işsletme Fakültesi / İşletme Bölümü/ fkiran@mehmetakif.edu.tr Orcid: 0000-0002-6456-2497 \\ ${ }^{3}$ Dr. Öğrencisi / Burdur Mehmet Akif Ersoy Üniversitesi / Sosyal Bilimler Enstitüsü / skaksoy@mehmetakif.edu.tr Orcid: 0000-0001-7473-5921 \\ ${ }^{4}$ Arş. Gör./ Burdur Mehmet Akif Ersoy Üniversitesi / Iktisadi ve İdari Bilimler Fakültesi / İşletme Bölümü/ dpehlivan@mehmetakif.edu.tr Orcid: 0000-0002-8058- \\ 6421
}

MAKALE BiLGILERi

Araştırma Makalesi Geliş Tarihi 7 Ekim 2020

Revizyon 12 Ekim 2020

Kabul tarihi 16 Ekim 2020

\section{Özet}

Bu çalışmanın amacı çalışanların işyerlerinde yöneticilerinin davranışlarından kaynaklı oluşan mutsuzluklarının hangi liderlik tarzı ile giderilebileceğini tespit edebilmektir. Bunun yanında mutsuz eden yönetici davranışlarından hangisinin daha sık görüldüğü ve mutlu eden yönetici davranışlarından hangisinin daha çok beklendiği de araştırmanın çözümlemeyi amaçladığı sorular olmuştur. Mutsuz eden yönetici davranışları ve çalışma kapsamına alınan liderlik tarzları senaryolaştıılarak 151 katılımcıya anket tekniği ile sunulmuştur. Araştırmanın bulgularına göre mutsuz eden yönetici davranışları karşısında en fazla beklenen liderlik tarzı otantik liderlik olmuştur. En fazla adaletsizlik, iletişim yetersizliği ve aşırı rol yükü olumsuzları ile mutsuz olduklarını belirten katılımcılar; güvenilir, pozitif iletişim kuran ve sonuç/çözüm odaklı yöneticiler arzu etmektedir.

Anahtar Kelimeler: Liderlik, Liderlik Tarzları, İşyerinde Mutluluk

\section{A scenario research on the leadership styles that expected from managers who make sad}

\section{ARTICLE INFO}

Research Article

Received 7 October 2020

Received in revised form

12 October 2020

Accepted 16 October

2020

\section{Abstract}

The purpose of this study is determining which leadership style can eliminate employees' sadness arising from the behavior of their managers in workplaces. In addition, the research aimed to analyze which manager behaviors who make sad are seen more frequently and which of the manager behaviors that made the happy are expected more. Manager behaviors which make sad employees and leadership styles which were included in the study were scenarized and presented to 151 participants with a questionnaire technique. According to the findings of the study, authentic leadership is the most expected leadership style in the face of manager behaviors who make sad. Participants who stated that injustice, lack of communication and excessive role burden make them unhappy; prefer reliable, communicating positively and result oriented managers.

\section{GíRiş}

Yöneticiler işletmelerin amaçlarına ulaşmalarında, kültürün de etkisi göz önüne alındığında; çalışan performansını artırabilecek kilit bir roldedir. Birçok farklı araştırma göstermektedir ki; yöneticilerin liderlik yaklaşımları, çalışanların motivasyonunu (Koçak ve Özüdoğru, 2012; Uluköy, Kılıç ve Bozkaya,2014), işin anlamlılık derecesi (Arnold vd. 2007), mutluluk seviyelerini (Kılınç ve Akdemir, 2019), duygusal bağlılıklarını (Çekmecelioğlu, 2014), işletme performansını (Yammarino ve Bass 1990; Hennessey 1998; Leli 1999: 81; Shea 1999)olumlu yönde değiştirebilmektedir. Fakat, işletmenin başarısına olumlu katkısı bulunan liderlik yaklaşımlarında -farklı sektörler, farklı nitelikte işler ve insanlar olduğu için, yani farklı bağlamlar bulunduğu için-kesin sınırlarla belirlenmiş davranışlar mevcut değildir. Liderlikte durumsallık teorisinin de üzerinde durduğu; liderin kişiliği ve tecrübeleri, üstlerin beklentileri ve davranışları, gerçekleştirilmek istenen amacın niteliği, örgütsel hava ve örgüt politikaları, diğer yöneticilerin özellikleri ve beklentileri, izleyicilerin beklentileri ve davranışları (Koçel, 2015: 686-687) ile çevresel belirsizlik koşulları (Liderlik Tarzları,2020) gibi faktörlerin etkili olduğu farklı koşullar altında değişmekte, farklı durumlar farklı liderlik tarzları gerektirmektedir (Koçel, 2015: 686-687). Örneğin gücünü kullanarak otoritesini kurmaya çalışan liderlerin başarıya ulaştığı durumlar olmakla birlikte, bu liderlik tarzı zamanla değişen koşullar neticesinde artık anlamını yitirmekte olduğu dile getirilmektedir (Küçük ve Yavuz, 2018:s.82). Artık çalışanının kendini psikolojik olarak refah içerisinde hissedeceği, böylece psikolojik güven içerisinde daha fazla inisiyatif alabileceği ortamlar oluşturan, çalışanların içsel motivasyonlarına erişen ve kendilerini gerçekleştirebilmeleri için zemin hazırlayan yönetici beklentileri mevcuttur. Çünkü hız ve rekabet zaten çalışanların kendilerini yorgun, gergin ve bazen de umutsuz hissetmesi işi ve örgütü ile ilgili bakış açısını negatif hale getirebilmektedir.Bu durum; motivasyon ve tatmin ile ilgili noktalardaki oluşan mutsuzluklarla paralel olarak, yöneticilerden ve örgütlerden beklentileri arttırmakta, yönetici davranışlarını daha belirleyici noktaya getirmektedir (Baykal vd., 2018:s.112). Çalışanları motive edecek, onların örgüte bağlılıklarını pekiştirecek ve çalışmalarında destek olacak liderlerin bulunması her organizasyonda büyük öneme sahiptir. Dolayısıyla son dönemlerde bakış açısı farklı ve insanlara yardımcı olmaya istekli olan liderler ön plana çıkmaya başlamıştır (Küçük ve Yavuz, 2018:s.82).

Bu araştırma çalışanların beklentileri üzerine, işyerinde yöneticileri tarafından mutsuz edildiği varsayılan çalışanların hangi liderlik tarzı ile mutlu edilebilecekleri üzerine kurgulanmıştır. Ek 1'de yer alan mutsuzluk senaryoları karşısında hangi liderlik tarzının bu olumsuz durumu giderebileceği araştırmaya konu edilmiştir. Bu temel amacın yanında, mevcut durumda çalışanları en fazla mutsuz eden yönetici davranışları, çalışanların yöneticilerden beklentileri ve demografik özelliklerle liderlik tarzı seçimi arasındaki ilişki de çalışma kapsamında incelenen diğer hususlar olmuştur.

\section{Kavramsal Çerçeve}

Lider; belirli koşullar altında, kişisel veya grup amaçları doğrultusunda başkalarını özgür iradeleri ile yönlendiren, takipçilerine ilham veren ve etkileyen kişidir (Koçel, 2015: 668). Alanyazında liderlikle ilgili farklı yaklaşımlar bulunmaktadır (Akbolat vd., 2013:s.3). Farklı bağlamlar farklı yaklaşımları gerekli kılmıştır. Özellikle pozitif liderlik yaklaşımları olarak ifade edilen hizmetkar liderlik, dönüşümcü liderlik, otantik liderlik ve kültürümüz bağlamında dikkate almamız gerektiği düşünülen babacan liderlik bu çalışmanın kapsamını oluşturmuştur. 


\section{Hizmetkar Liderlik}

İlk defa 1970'lerin başında Robert Greenleaf tarafından önerilen hizmetkar liderlik tarzının esası liderin işinin ilk ve tek önceliği kendisini izleyenlere 'hizmet' etmektir (Koçel,2014:s.686). Fakat bu ifadede altının çizilmesi gereken husus, astlarına hizmet etme kavramının takipçilerine köle olma anlamına gelmediği; mesleki ve manevi gelişmesi için takipçilerinin ihtiyaçlarına hizmet etme isteğini ifade ettiğidir (Ruíz vd. 2010: 47). Hizmetkar liderlerin nihai amacı, hizmet edilen çalışanların iş tatminlerini yükselterek örgüte bağlılıklarını arttırmak ve onların da birer hizmetkar lider olmalarını sağlamaktır (Günaydın vd, 2016: 26). Bu doğrultuda hizmetkar lider, izleyicileri ile arasında bir birliktelik ruhu yaratmaya çalışır, kararlara katılımcı bir tarzı vardır, ikna yöntemini benimser (Koçel,2014:s.686), takipçilerinin birey olarak gelişmelerini sağlar ve bunun için gerekli ortamı yaratmaya çalışır(Koçel,2014:s.686; Kahveci ve Aypay, 2012: 20; Günaydın vd, 2016: 26), çalışanlarına karşı bencillikten uzaktır (Günaydın vd, 2016: 26), öz farkındalığa sahiptirler ve bu özelliklerini başkalarının kendini gerçekleştirmeleri için kullanır (Alparslan vd., 2019: s.60), takipçilerinin çıkarlarını kendi bireysel çıkarlarının önünde tutar, örgütün amaçlarını gerçekleştirmenin yan sıra toplumun ve diğer paydaşların da menfaatlerini korumayı hedefler (Çetinkaya ve Yıldız,2018:s.2), tutarlı davranış sergiler, insanlara güven telkin eder, kimseyi kandırmaz, bilgileri çarpıtmaz ve manipüle etmez (Baykal vd.,2018:s.114).

\section{Dönüşümcü Liderlik}

İlk defa 1978 yılında McGregor Burns'ün "Liderlik" adlı kitabında yerini bulan dönüşümcü liderlik kavramı, daha sonra Bernard Bass ve arkadaşları tarafından dönüşümcü liderlik teorisi olarak geliştirilmiştir (Akbolat vd., 2013:s.36).Dönüşümcü liderlik vizyonu faaliyete geçirmek adına takipçileri güçlendirme, yetki verme ve verdiği bu yetkiyi, gücü eylem birliğine çevirme becerisidir (Bennis, 1985'den aktaran Alper Ay ve Keleş,2017; 195). Özellikle örgütler arasındaki yerel ve uluslararası rekabetin çok ciddi olarak arttığı ortamlarda öne çıkan dönüşümcü liderlik (Eren ve Titizoğlu, 2014:s.278), bünyesinde karizma veya idealleştirilmiş etki, esinlenmiş motivasyon, entelektüel uyarım ve bireysel destek özelliklerini barındırır. Karizma veya Idealleştirilmiş Etki: Karizma, liderle kimliğini bulan güçlü duygular uyandırarak izleyenleri etkileyebilme sürecidir. Bu özellik izleyenlerde hayranlık, saygı ve güven duygusunu ortaya çıkarır. Takipçilerin liderleriyle özdeşleştirmesini sağlar. Lider, kendine güvenir, kararlıdır, tutarlıdır ve risk almaya isteklidir. (Cömert,2004:s.2-3). İdealleştirilmiş etki ise, liderin izleyenleri ile etkileşimde bir vizyon oluşturma ve misyon belirleme davranışlarııı içerir. Liderin etkisi, özellikleri ve davranışları izleyenleri tarafından idealleştirilmiştir. (Cömert,2004:s.2-3).Takipçiler bu liderlere son derece güven duyarlar (Ayça,2016:s.18).Esinlenmiş Motivasyon (ilham Verme, Telkinle Güdüleme): Lider gelecek için harekete geçirici, gruba ivme kazandıran bir vizyon oluşturarak bu vizyonu gerçekleştirmede azim ve kararlık gösterir (Cömert,2004:s.3). Iletişim yeteneğiyle yüksek beklentiler üzerine iletişim kurar. İyimserlik ve heyecan ön planda olduğundan takım ruhunu ateşler. Takipçileriyle ortak normları ve değerleri olduğundan kültürel bir etkileşim yaratırlar (Ayça,2016:s.18).Entelektüel Uyarım: İzleyicilerin problemleri daha fazla farkına varmaları, farklı, yeni bir bakış açısıla problemleri görebilmelerini sağlamaya yöneliktir. Lider, güçlüklerle ve engellerle baş edebilmek için, daha önceden de var olan problemler hakkında yeni bakış açıları oluşturmalarını sağlayarak, astların alışılagelmiş davranış ve düşünüş kalıplarını sorgulamalarını gerçekleştirir. Böylece astlar öteden beri var olan kabullenmeleri ve geleneksel çözüm yollarını sorgulayabilir (Cömert,2004:s.3). Takipçilerinin bilgi, beceri ve yeteneklerini ortaya çıkarmak için üst düzey çaba sarf eder. Entelektüel güçlerini ortaya çıkarır (Ayça,2016:s.18).Bireysel Destek: İzleyenlere bilgi, beceri ve deneyimlerini geliştirerek destek sağlama, özendirme sürecidir. Lider, temelde ekip elemanlarının kişisel ihtiyaçlarına eğilir. Astlarıyla birebir ilişkiler kurar ve onların kişisel gelişmelerine önem verirler. Empati kurma becerileri gelişmiştir(Cömert,2004:s.3-4).Organizasyonun bütün çalışanlarına aynı ilgi ve özenle davranıp, takipçilerinin mentorluk ve koçluğunu yapar (Ayça, 2016:s.18).

\section{Otantik Liderlik}

Otantiklik, "kendini bilmek ve kendini doğru ifade edebilmek" anlamına gelmektedir. Liderler ve izleyiciler otantiklik kavramını "doğuştan gelen bir özellik", şeklinde algılamaktadırlar; aslında otantiklik izleyicilerin lidere atfettiği bir özelliktir (Kesken ve Ayyıldız, 2008: 736). Otantik liderlik "bireyin kişisel tecrübelerini sahiplenerek, düşüncelerinin, duygularının, ihtiyaçlarının, isteklerinin, tercihlerinin ya da inançlarının, ne yaptığını bilme uyarısı kapsamında işlenmesi” olarak tanımlanabilir (Ayça, 2016:s.27).

Araştırmacıların ve akademisyenlerin çoğu, otantik liderliğin dört bileşenden oluştuğunu ifade etmektedirler. Öz farkındalık: Bir bireyin yaşamdan nasıl anlam çıkardığı ve bu çıkardığı anlamın o bireyin zaman içerisinde kendisini değerlendirme biçimini nasıl etkilediğini kavraması olarak ifade edilmektedir. Ayrıca bu kavram, bireyin güçlü ve zayıf yönlerinin bilmesini, diğerlerine bakarak kendini anlayabilme becerisini kazanmasını ve bireyin diğerleri üzerindeki etkisinin farkında olmasını da içermektedir (Hırlak ve Taşlıyan, 2016:s.94). ilişkisel şeffafıł: Kendi kendini açıkça ifade edebilmek, uygun olmayan etkileri en aza indirmeyi amaçlayan gerçek duyguların anlatımı anlamına gelmektedir (Hırlak ve Taşlıyan, 2016:s.94). Temelde liderin gerçekte olan kişiliğinin astları tarafından görülmesine yardımcı olan bir unsurdur. Lider, kendisini en uygun şekilde ifade ederek, farklı ve önemli olan unsurların yanı sıra nihai amacı olan güveni sağlamaya çaba göstermektedir. (Karacaoğlu ve Satır, 2019:s.93). Karar almada bilginin dengeli değerlendirilmesi: Karar vermeden önce objektif bir biçimde tüm ilişkili verileri analiz etmek anlamına gelmektedir (Hırlak ve Taşlıyan, 2016:s.94). Objektif değerlendirme yapabilen liderler elde edilen bu bilgileri daha az hata ile yorumlamakta, becerilerini daha iyi değerlendirebilmekte ve aynı zamanda öğrenme potansiyelindeki kendisini zorlayan noktaları tespit etmeye çalışmaktadır (Karacaoğlu ve Satır, 2019:s.92-93). Içselleştirilmiş ahlak anlayışı: Kişinin değer kalıpları, seçimleri ve gereksinimleri ile uyum içinde davranışlar sergilemesi anlamına gelmektedir (Karacaoğlu ve Satır, 2019:s.93). Özellikle ahlaki ikilemleri çözebilmek için otantik liderlerin doğasında; üst düzey ahlaki standartlar ve yetenekler olduğunu ifade etmektedirler. (Karacaoğlu ve Satır, 2019:s.93).

\section{Babacan (Paternalist) Liderlik}

Babacan liderlik, liderin astına karşı hem iş yerinde hem de iş dışı hayatında özen gösterdiği, onu yönlendirdiği ve koruduğu bunun karşılığında da asttan itaat ve saygı beklediği hiyerarşik bir ast üst ilişkisi olarak tanımlanmaktadır (Bekmezci ve Yıldız, 2019:s.311). Babacan liderlik, liderin kendisini takip edenlere bir baba gibi davranması anlamını içermektedir. Babacan lider, takipçilerinin işlerine yoğunlaşması için onların aile sorunları dahil yardıma ihtiyacı oldukları her konuda her çeşit yardımı yapar, onlar için endişelenir ve sonuç olarak çalışanlardan sadakat bekler (Nal ve Tarım,2017:s.119).

Babacan lider, bir aile olarak algılanan organizasyondaki diğer bireylere ailenin bir üyesi olduklarını hissettirir. Bunu sağlamak için, yeni bir uygulamayı nasıl gerçekleştireceklerini, olması gerekenleri onlara anlatır, elde edilen sonuca göre onları zamanı geldiğinde ödüllendirir ya da ikaz eder. Çalışanlar, sorumluluk alma konusunda teşvik edilirler ve sorunlar istenilen şekilde çözülürse babacan liderin mutlu olacağını düşünmektedirler. Çalışanlar, liderin istediği davranışı gösterir ve itaat ederler ise kendilerini lidere sevdirirler ve daha motive olmuş bir biçimde harekete geçerler (Nal ve Tarım,2017:s.120).Babacan liderlik, sosyoekonomik ve kültürel etmenlere bağlı olarak özellikle doğu toplumlarında daha etkili olduğu savunulan bir liderlik türüdür. Otoriterlik, yardımseverlik ve ahlak olmak üzere üç boyuttan oluşmaktadır. Astının iyi oluşuna özen gösterir ve onlarla birebir ilgilenir, ahlaki değerleri ön planda tutar (Gerçek, 2018:s.101-102).

\section{Liderlik Yaklaşımları ve İşyerinde İyi Oluş (Mutluluk) ilişsisi Üzerine Literatür Taraması}

Alan yazını incelendiğinde liderlik/liderlik türleri ve iyi oluş arasındaki ilişkiyi inceleyen birçok çalışma bulunmaktadır. Dünyanın çeşitli bölgelerinde ve farklı kültürlerde yapılan bu çalışmalar, liderlik davranışının çalışanın iyi oluşu üzerindeki etkisinin evrensel olduğunu göstermektedir. Ancak farklı örneklemler ve bağlamlar, liderliğin farklı özelliklerinin daha baskın olmasını gerektirebilir. Liderlikte lider kadar izleyici özelliklerinin ve bağlamın da önemli olduğu durumsal yaklaşımın temel öğretisidir (Koçel, 2018: s.601). Örneğin Maula-Bakhsh ve Raziq (2013), işçiler üzerinde yaptığı araştırmada; işçilerin öznel iyi oluş durumunda hizmetkar liderliğin önemli bir rol oynadığını ortaya koymakta, hizmetkâr liderliğin, çalışanın olumlu ve yapıcı duygu ve duygulara sahip olma derecesini belirlediğini göstermektedir. Aynı yazarların 2018 yılında yaptıkları çalışma sonuçları hizmetkâr liderliğin özellikleri (duygusal iyileşme, güçlendirme ve kavramsallaştırma) ile öznel iyi olmanın duyuşsal boyutu arasında anlamlı ilişkisini tekrar ifade etmiştir (Maula-Bakhsh ve Raziq, 2018). Kinderen vd. (2020) 
tarafından yapılan çalışma ise, hizmetkar liderliğin, işyerinde nezaket ortamında psikolojik iyi oluş ile daha güçlü bir ilişkiye sahip olduğu belirtmektedir. Nie ve Lamsa (2018), Finlandiya'da çalışan Çinli göçmenler üzerine yaptıkları araştırmada ise babacan liderliğin boyutlarının; özellikle yardımsever liderlik davranışının, iş̧̧ilerin iyi oluşlarında etkili olabileceğini göstermişlerdir. Daha samimi ve içten yaklaşan, güven ve destek iklimini oluşturan hizmetkar ve babacan liderler oluşturdukları güven ve destek iklimi hem öznel hem de psikolojik iyi oluşun zeminini oluşturabilmektedirler.

Literatürde iyi oluşla en sık ilişkilendirilen dönüşümcü liderlikle ilgili çalışmaların ne ifade ettiklerini daha detaylı anlamak gerekir. Atar ve Konaklığlu (2018), Türkiye ve İtalya üzerine yaptıkları bir çalışmada dönüşümcü liderlik ile psikolojik iyi oluş arasında ilişki olduğunu belirtirken, Ayan, Ünsar ve Oğuzhan (2016) dönüşümcü liderlik tarzının hem duygusal tükenmeyi hem de duyarsızlaşmayı negatif yönde etkilediğini belirtmektedirler. Nielsen ve Daniels (2012), iyi olma çıktılarında farklılaştııılmış liderliğin, grup düzeyindeki dönüşümcü liderlik algısından daha geniş bir yelpazede rol oynadığını göstermektedir. Liu vd. (2010) ve Kelloway vd. (2012) tarafından yapılan ayrı çalışmalarda dönüşümcü liderlik ve psikolojik iyi oluş arasında lidere duyulan güvenin aracılık rolü olduğu belirtilmiştir. Dönüşümcü liderliğin dışsaldan ziyade içsel unsurları harekete geçirici ve böylece dönüştürücü tavrı daha gerçek ve daha uzun süreli iyi oluşa sebep olabilmektedir.

Son zamanlarda hem bireysel bazda hem de liderlik bağlamında öne çıkan bir başka tavır ise otantiklik tavrıdır. Erkutlu ve Chafra (2014) yaptıkları çalışmada otantik liderlik ve örgütsel işe gömülmüşlük arasında önemli ve olumlu bir ilişki olduğunu ortaya koymuşlardır. Nelson vd. (2014) hemşireler üzerinde yaptıkları çalışmada otantik liderliğin işyeri ortamını olumlu etkilediğini ve bunun bireye yansıdığını vurgularken; Kılınç ve Akdemir (2019) otel çalışanlarında otantik liderlik algı seviyesindeki artışın, işyeri mutluluğunu olumlu etkilediğini tespit etmiştir. Öcal ve Barın (2016) otantik liderlik davranışının, örgütlerde pozitif psikolojik sermayenin yapı taşlarından biri olduğunu ve örgütlerde negatif koşullar ile mücadeleyi kolaylaştırdığını belirtmektedir. Çalışmasında otantik liderliğin işe yabancılaşmayı azalttı̆ı̆ını ve bu negatif ilişkinin özellikle içselleştirilmiş ahlak anlayışı ve şeffafılık boyutları açısından daha anlamlı olduğunu tespit etmiştir. İyi oluşun üç boyutu ve otantik liderlik arasındaki ilişkiyi inceleyen çalışmalarında Rahimnia ve Sharifirad (2015), otantik liderliğin iş tatminini artıırken, algılanan stres ve stres belirtilerini azalttığını bulmuştur. Ilies vd. (2005) otantik liderlerin, takipçilerinin iyi oluşunu nasıl etkilediğini şu şekilde açıklamaktadır: ilk olarak, otantik liderlerin kişisel bütünlüğü ve yüksek öz farkındalığı sayesinde doğru ilişkilere ve takipçilerin kayıtsız şartsız güvenine yol açar. İkinci olarak, otantik liderler, takipçilerin mutluluğunu duygular yoluyla etkiler: otantik liderler, olumlu duyguların deneyimine elverişli bir atmosfer sağlar ve kendi olumlu duygularını da bulaşmasını sağlar. Üçüncüsü, liderler; kendini samimi biçimde ifade eden bir model olarak örnek olurlar. Dördüncüsü, otantik liderler, kısmen beceri geliştirme ve özerklik için fırsatlar sağlayarak, takipçilerin kendi kaderini tayin etmelerini destekler. Son olarak, otantik liderler sosyal paylaşımlar yoluyla, takipçilerinin modunu olumlu manada yükseltirler. Bu araştırmalar bağlamında otantikliğin hakiki, samimi ve içten tavrının; karmaşıklığı, sahteliği ve güvenirliği yıpranmış bir zamanda beklenen bir tarz olduğu yorumlanabilir.

\section{Araştırmanın Kapsamı ve Amacı}

İlgili literatür taramasının da gösterdiği gibi çalışanların iş yerindeki iyi olma halinde yöneticilerin pozitif liderlik yaklaşımlarının önemli düzeyde olumlu bir etkisi bulunmaktadır. Bu çalışma kapsamında da hizmetkar, dönüşümcü ve otantik liderlik gibi pozitif liderlik yaklaşımları olarak ele alınan bu tarzların mevcut durumda hangisinin daha etkili olabileceği sorgulanmaktadır. Ayrıca kültür bağlamı da dikkate alınarak babacan liderlik de araştırma kapsamına alınmıştır. Bu doğrultuda araştırmanın amacı; çalışanları iş yerinde mutsuz eden durumlarda, yöneticinin göreli olarak daha fazla sergilemesi beklenen liderlik tarzını tespit etmektir. Böylece çalışmanın ortaya koyabileceği diğer önemli bir bulgu da; çalışanları en fazla mutsuz eden yönetici davranışları ortaya koymaktır. Son olarak çalışanların yöneticilerden beklentileri ve demografik özelliklerle liderlik tarzı seçimi arasındaki ilişki de çalışma kapsamında incelenen diğer hususlar olmuştur.

\section{Veri Toplama Aracı}

Araştırmada nicel veri toplama tekniklerinden olan anket tekniği kullanılmıştır. Anket metninde ilk olarak hizmetkar liderlik, dönüşümcü liderlik, otantik liderlik ve babacan liderlik tarzlarının özellikleri hakkında katılımcılara bilgi verilmiştir. Liderlik tarzlarıyla ilgili bilgilendirmenin hazırlanmasında literatürdeki ölçeklerden, ölçeklerin boyutlarından ve ifadelerinden yararlanılmış, ayrıca oluşturulan bu tanımlamalarda uzman görüşlerine başvurulmuştur. Üç uzmanın görüşünden sonra tanımlamalar aşağıdaki şekilde katılımcılara sunulmuştur.

\section{Hizmetkar Liderlik;}

Kendinden ziyade başkalarını düşünen, çıkar gözetmeden yardım etmeyi ve fayda sağlamayı görev bilen bir yöneticidir. Sorunları çözmede çalışanlarına güvenir ve sorumluluk verir. Toplum yararına bir vizyon oluşturarak alçak gönüllü bir tavırla çalışır.

Dönüşümcü Liderlik;

Çalışanlara kurumun uzun vadeli hedeflerini anlatır. Gelecekle alakalı iyimser ve hevesli bir tavırla insanlarda ilgi uyandırır ve motive eder. Problemlere farklı bakış açılarından bakmanın yollarını gösterir. Çalışanlarını tek tek tanır. Onların güçlü yönlerini ve ihtiyaçlarını göz önünde bulundurarak zamanla onları geliştirir.

\section{Otantik Liderlik;}

Kararlarını ahlaki değerlere göre vermeyi önemseyen yönetici, değerlerinden asla ödün vermez. Ama hata yaptığında da bunu açıkça söylemesini bilir. Çalışanlarından da aynı biçimde düşündüklerini açıcça söylemesini bekler. Yeteneklerinin ve zaaflarının farkındadır, çalışanlarının kendi hakkında ne düşündüğünü önemser. Olaylara mümkün olduğunca tarafsız bir gözle bakıp karar vermeden önce farklı bakış açılarını dikkate alır.

\section{Babacan Liderlik;}

İs yerinde aile ortamının oluşmasını önemser. Tıpkı bir baba gibi her bir çalışanıyla ilgilenir, iş dışındaki hayatına katkı sağlar, sevinçlerini de üzüntülerini de paylaşır. Bununla birlikte otoritesine saygı duyulmasını ve kendisine sadık olunmasını bekler.

Anket soruları üç bölümden oluşmaktadır ve tüm sorular çoktan seçmelidir. İlk bölümde Alparslan vd. (2019)'un çalışanları mutsuz eden yönetici davranışları hakkındaki araştırma sonuçlarından yararlanılmıştır. Bu bölümde, çalışanları mutsuz eden 10 yönetici davranışı senaryolaştırılmıştır (Ek-1). Bu senaryolara yönelik uzman görüşü alınmış ve geri dönüşler doğrultusunda senaryolar revize edilmiştir. Katııımcılardan senaryoları yaşadıklarını farz etmeleri ve yaşadıkları bu olumsuzları olumlu hale getirebileceğini düşündükleri liderlik tarzını seçmeleri istenmiştir. Anketin ikinci bölümünde katılımcıların demografik özelliklerine yönelik sorular bulunmaktadır. Son bölümde ise Alparslan vd. (2019)'un çalışanları mutsuz eden yönetici davranışlarının yanında çalışanları mutlu eden yönetici davranışlarını inceledikleri çalışmadan yararlanılmıştır. Bu bölümde çalışanların en fazla karşılaştığı mutsuz eden yönetici davranışları ile liderden beklediği davranışların seçilmesi istenmiştir.

\section{Araştırmanın Örneklemi}

Araştırmanın evrenini Türkiye'de hem kamu hem de özel sektörde bulunan çalışanlar oluşturmaktadır. Araştırma örneklemi; tesadüfü olamayan kolayda örneklem yöntemi kullanarak oluşturulmuştur ve 151 çalışana ulaşılmışır. Katılımcıların demografik özellikleri Tablo 1'de verilmiştir.

Tablo 1: Katılımcıların demografik özellikleri

\begin{tabular}{lllll}
\hline Demografik Değişken & & Frekans & Yüzde \\
\hline Cinsiyet & Kadın & 79 & 52,3 \\
\hline & Erkek & 72 & 47,7 \\
\hline Yaş & $20-30$ & 39 & 25,8 \\
\hline & $31-40$ & 79 & 52,3 \\
\hline
\end{tabular}




\begin{tabular}{llll}
\hline & 41 ve üstü & 33 & 21,9 \\
\hline Eğitim Düzeyi & ilköğretim - Ortaöğretim & 10 & 6,6 \\
\hline & Önlisans-Lisans & 93 & 61,6 \\
\hline & Lisansüstü & 48 & 31,8 \\
\hline Sektör & Kamu & 125 & 82,8 \\
\hline & Özel & 26 & 17,2 \\
\hline Gelir & $0-$ Asgari ücret & 14 & 9,3 \\
\hline & Asgari ücret - 4000 TL & 54 & 35,8 \\
\hline & 4001 TL - 7000 TL & 73 & 48,3 \\
\hline Kurumdaki Yılı & 7000 TL üzeri & 10 & 6,6 \\
\hline & 5 yıldan az & 63 & 41,7 \\
\hline & $6-10$ yıl & 55 & 36,4 \\
\hline & 10 yıldan fazla & 33 & 21,9 \\
\hline
\end{tabular}

Tablo 1'e göre katııımcıların kadın erkek oranı benzer düzeydedir. Önemli bir kısım (\%52,3) 31-40 yaş aralığındadır. Önlisans ve lisans mezunları örneklemin \% 60'ını oluşturmaktadır. Çalışanların çoğunluğu kamu kurumlarında çalışmaktadır ve neredeyse yarıının $4001 \mathrm{TL}-7000 \mathrm{TL}$ arasında geliri bulunmaktadır. Katılımcıların \%41,7'si şu an çalıştığı kurumda 5 yıldan az süredir çalışmaktadır.

\section{Araştırmanın Bulguları}

Çalışmada ilk olarak çalışanları mutsuz eden yönetici davranışları sorgulanmıştır. Alparslan vd. (2019)'un ortaya koyduğu yönetici davranışları üzerinden, bu çalışmadaki katılımcılara hangi olumsuzlukları daha fazla yaşadıkları sorulmuştur. Araştırma sonuçları Şekil 1'de yer almaktadır. Şekil 1'de görüldüğü üzere; çalışanlar en fazla sırasıyla iletişim yetersizliği (88 katılımcı), adaletsizlik (87 katılımcı), çalışanları önemsememe (44 katılımcı), aşırı rol/ iş yükü (44 katılımcı), güvensizlik (39 katıımcı), kendini önemseme/ benlik yönelimi (37 katılımcı), art niyetli davranışlar (26 katılımcı), olumsuz geri bildirim (19 katıımcı), aşırı nezaret/hiyerarşik tavır (12 katılımcı) ve doğrudan saldırgan davranışlar (6 katılımı) gibi olumsuz durumlarla karşılaştıklarını dile getirmişlerdir. Bu sonuçlar çalışanların yaklaşık \%60'ının yöneticilerinin adaletsiz davranışlarına ve iletişim yetersizliklerine maruz kaldığını göstermektedir.

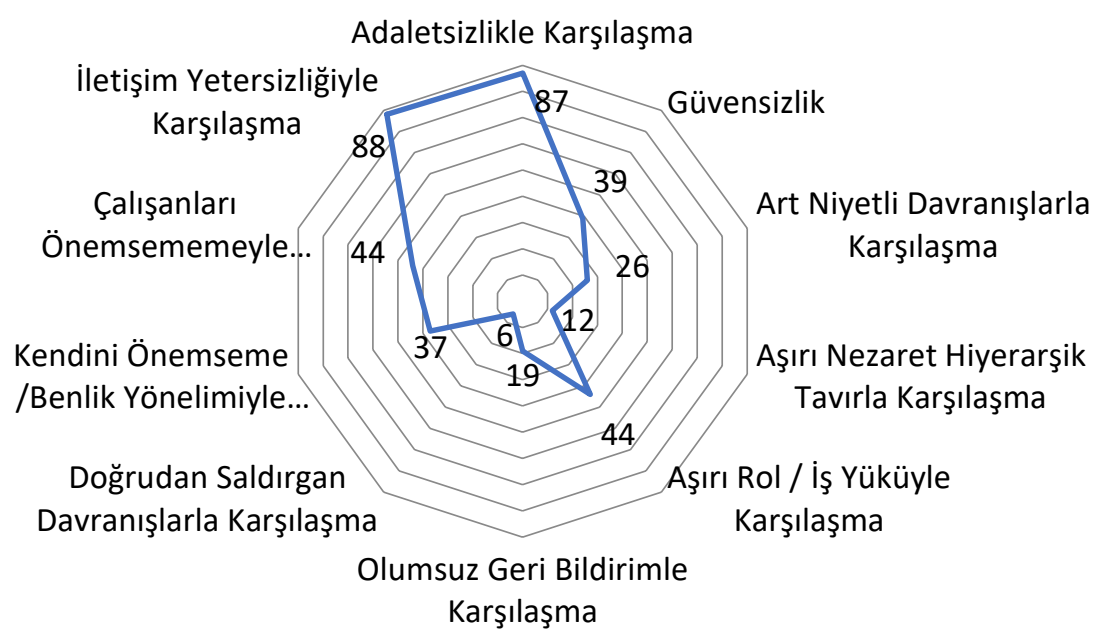

Şekil 1: Çalışanların en fazla karşılaştığı mutsuz eden yönetici davranışları dağılımı

Araştırmada katılımcılardan; çalışanları mutsuz eden yönetici davranışlarına dair senaryolara göre olumsuz durumu düzeltebilecek liderlik tarzlarının seçilmesi istenmiş̧ir. Olumsuz durumlar ve tercih edilen liderlik tarzları Şekil 2'de yer almaktadır. Şekil 2'de görüldüğü üzere; katılımcıların büyük çoğunluğu adaletsizlik (f:55), güvensizlik (f:75), art niyetli davranışlar (f:71), olumsuz geri bildirim (f:70), doğrudan saldırgan davranışlar (f:61) ve çalışanları önemsememe (f:61) durumlarında otantik liderlik özelliklerine sahip yöneticileri tercih etmişlerdir. Aşırı rol iş yükü (f:63) ve iletişim yetersizliği (f:68) gibi olumsuz durumlarda dönüşümcü liderlik özelliğine sahip yöneticilerin daha olumlu etki oluşturacağı görülürken, hizmetkar liderliğin ise; kendini önemseme, benlik yönelimi (f:54) gibi durumlarda etkili olacağı görülmüştür. Öte yandan her ne kadar verilen tüm olumsuz durumlarda babacan liderlik özelliklerine sahip yönetici talebinde bulunan katılımcılar mevcutsa da hiçbir durumda çoğunluğun arzu ettiği bir yaklaşım durumunda olmamıştır. Genel olarak 10 olumsuz duruma ilişkin 151 katılımcının hangi liderlik yaklaşımlarını tercih ettiğine dair bilgi vermek gerekirse; sırasıyla otantik liderlik (f:552), dönüşümcü liderlik (f:410), hizmetkar liderlik (f:307) ve babacan liderlik (f:241) olduğu görülmüştür. 


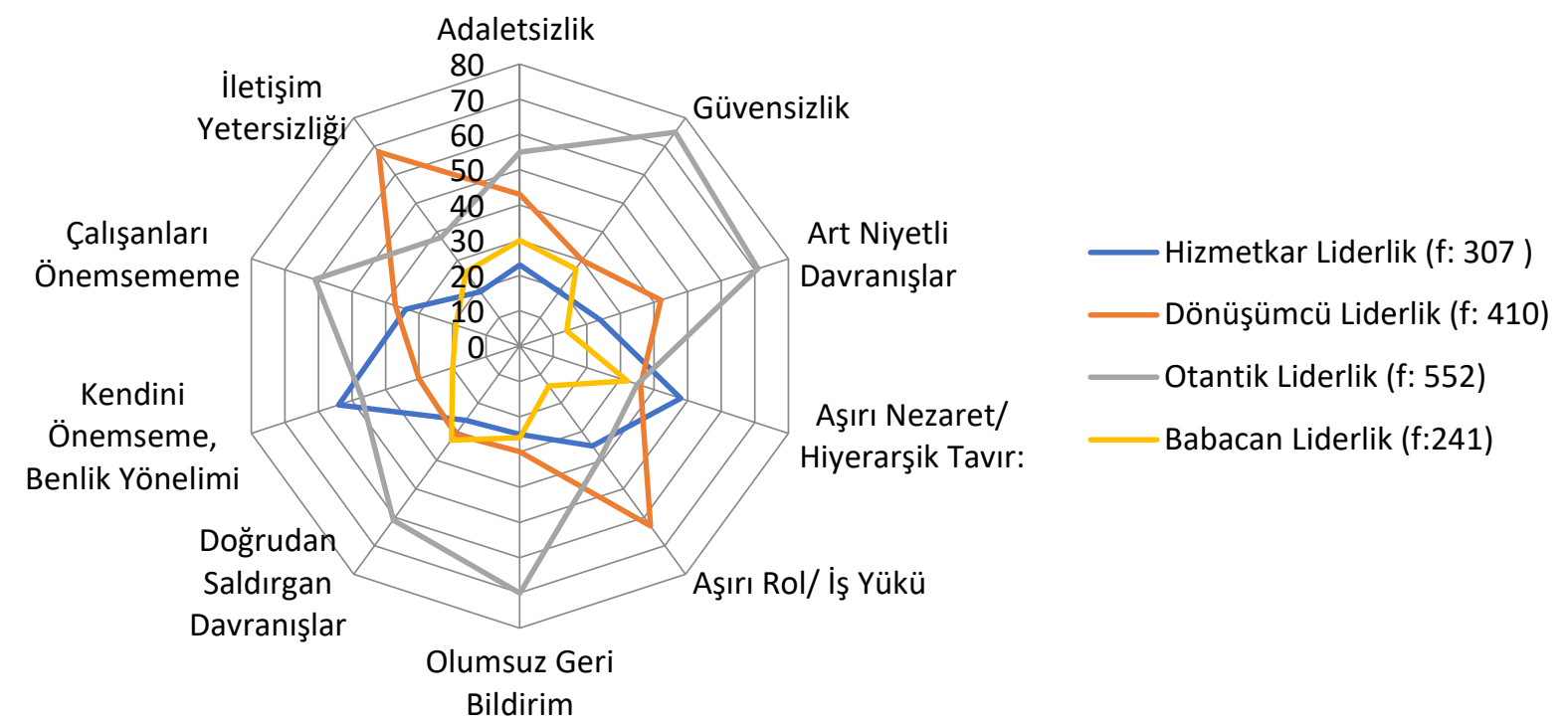

Şekil 2: Mutsuz eden yönetici davranışları senaryolarında çalışanların tercih ettiği liderlik tarzları dağılımı

Araştırmanın bir diğer sorguladığı husus ise çalışanların en fazla bekledikleri “mutlu eden yönetici davranışları”nın neler olduğudur. Araştırma bulgularına göre en fazla sonuç ve çözüm odaklı (f:80 katılımcı) olmaları beklendiği saptanmıştır. Ardından yöneticilerin en fazla benzer oranda güvenilir (f:72) ve pozitif iletişim kuran (f:71) insanlar olmaları beklenmektedir. Bunun dışında sırasıyla çalışanlarını güçlendiren ve katılımlarını sağlayan (f:53), pozitif dayanışma ortamı sağlayan (f:47), insani davranışlar sergileyen (f:45), çalışanların eğitim almasını destekleyen ve yetiştiren (f:33), olumlu geri bildirim veren ve ödüllendiren (f:29), vizyon sahibi olan ( $f: 18$ ) ve çalışanlarına bireysel ilgi gösteren (f:8) bireyler olmaları beklendiği tespit edilmiştir.

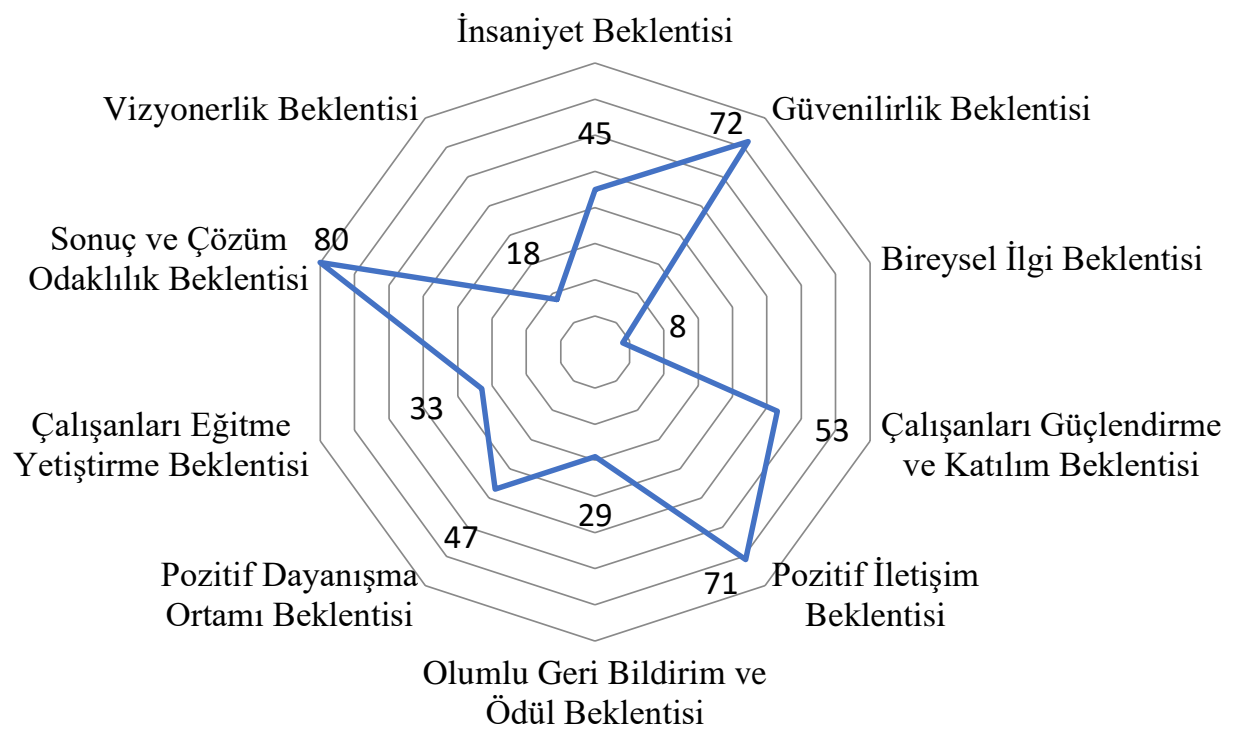

Şekil 3: Çalışanların en fazla beklediği mutlu eden yönetici davranışları dağılımı

Son olarak beklenen liderlik tarzları ile katılımcıların cinsiyetleri, yaşları, eğitim düzeyleri, sektörleri, gelirleri ve bulundukları kurumda çalışma süreleri Ki Kare bağımsızlık testi yapılarak karşılaştırılmıştır. Analiz sonuçları katılımcıların liderlik tarzları ile araştırma kapsamında sorgulanan demografik özellikleri arasında anlamlı bir ilişki olmadığını göstermiştir (Tablo 2). 
Tablo 2: Liderlik tarzları ile demograrik özellikleri ilişkisine dair analiz sonuçları

\begin{tabular}{|c|c|c|c|c|c|c|}
\hline & & $\begin{array}{l}\text { Hizmetkar } \\
\text { Liderlik }\end{array}$ & $\begin{array}{l}\text { Dönüşümcü } \\
\text { Liderlik }\end{array}$ & $\begin{array}{l}\text { Otantik } \\
\text { Liderlik }\end{array}$ & $\begin{array}{l}\text { Babacan } \\
\text { Liderlik }\end{array}$ & Sig. \\
\hline \multirow[t]{2}{*}{ Cinsiyet } & Kadın & 11 & 18 & 44 & 6 & \multirow{2}{*}{ 145 } \\
\hline & Erkek & 12 & 18 & 29 & 13 & \\
\hline \multirow[t]{3}{*}{ Yaş } & $20-30$ & 7 & 7 & 21 & 4 & \multirow{3}{*}{,930 } \\
\hline & $31-40$ & 12 & 20 & 37 & 10 & \\
\hline & $41-50$ & 4 & 9 & 15 & 5 & \\
\hline \multirow[t]{3}{*}{ Eğitim Düzeyi } & İlköğretim - Ortaöğretim & 0 & 1 & 9 & 0 & \multirow{3}{*}{,038 } \\
\hline & Önlisans-Lisans & 11 & 25 & 42 & 15 & \\
\hline & Lisansüstü & 12 & 10 & 22 & 4 & \\
\hline \multirow[t]{2}{*}{ Sektör } & Kamu & 18 & 28 & 62 & 17 & \multirow{2}{*}{616} \\
\hline & Özel & 5 & 8 & 11 & 2 & \\
\hline \multirow[t]{4}{*}{ Gelir } & 0-Asgari & 1 & 3 & 10 & 0 & \multirow{4}{*}{643} \\
\hline & Asgari- 4000 & 9 & 13 & 23 & 9 & \\
\hline & $4001-7000$ & 10 & 18 & 36 & 9 & \\
\hline & 7000 TL ve üzeri & 3 & 2 & 4 & 1 & \\
\hline \multirow[t]{3}{*}{ Kurumdaki yılı } & 5 yıldan az & 8 & 15 & 31 & 9 & \multirow{3}{*}{,872 } \\
\hline & 6-10 yıl & 9 & 11 & 29 & 6 & \\
\hline & 10 yıldan fazla & 6 & 10 & 13 & 4 & \\
\hline
\end{tabular}

\section{Tartışma ve Sonuç}

Farklı koşullar veya işletmedeki farklı problemler farklı yönetim yapılarını gerekli kılmaktadır. Fakat; uygulama ve literatür incelendiğinde koşulların çeşitlendiği ve yöneticilerin bu koşullara karşı kullanabileceği pek çok yönetim aracı olduğu görülmektedir. Bu durum belirsizliği arttırırken yöneticilerin de başarısını etkilemektedir. Uygulamada bulunan yöneticilere rehber oluşturmak adına tasarlanan bu araştırmada çalışanların yaşamış oldukları problemlerin ve beklentilerin tespiti, bu bulgulara dayanarak talep edilen liderlik tarzları ve bazı demografik değişikliklerin liderlik seçimlerine etkisinin saptanması amaçlanmıştır. Ancak örneklemin evrene göre düşük sayıda kalması ve örneklem yoğunluğunun daha çok kamu sektörü içinde kalması araştırmanın önemli sınırlılıklarını oluşturmaktadır.

Çalışanların en fazla karşılaştıkları (yöneticilerle ilgili olarak) adaletsizlik, iletişim yetersizliği ve aşırı rol yükü olmuştur. Adalet ve iletişim insani olarak da her düzlemde en temel hususlardandır. Pozitif iletişimin katkısı önemli olmakla birlikte bütüncül bir adalet hissi sağlanmadan faydası olmayabilir. Bulgulara göre adaletsizliğin yüklenen iş ve verilen rollerle ilgili olabildiği çıkarımı yapılabilir. Bu bağlamda yöneticilerin çalışanlarının görev tanımı ve dağılımı konusunu önemsemeleri gerekmektedir. Araştırmanın çözümlemeye çalıştığı temel husus çalışanları mutsuz eden bu yönetici davranışlarının bulunduğu koşullarda gerekli görülen liderlik tarzlarının tespitidir. Bulgular göstermektedir ki; adaletsizlik, güvensizlik, art niyetli davranışlar, olumsuz geri bildirim, doğrudan saldırgan davranışlar ve çalışanları önemsememe durumlarında otantik liderlik; aşırı rol iş yükü ve iletişim yetersizliği durumlarında dönüşümcü liderlik; yöneticinin kendini önemseme, benlik yönelimi durumlarında hizmetkar liderlik tarzının katılımcılar tarafından daha çok tercih edildiği görülmüştür.

Araştırma sonuçları incelendiğinde; 10 olumsuz duruma ilişkin en fazla tercih edilen liderlik yaklaşımının otantik liderlik olduğu görülmüştür. Kesken ve Ayyıldız (2008; 734-735)kişisel çıkarların ön planda tutulması, güvenilir liderlere duyulan ihtiyacın artması ve belirsizliklerin mevcut olması gibi nedenlerin umut, iyimserlik, öz-bilinç ve esneklik özelliklerine sahip liderlere olan ihtiyacı ortaya çıkardığını savunmaktadır.Ayrıca; çalışanlarda yöneticilerinin başarılarından emin olsalar dahi etik olup olmadıklarına dair şüphenin de var olduğunu düşünmektedir. Dolayısıyla bu düşünceler ışığında insanlar "oldukları gibi görünüp, göründükleri gibi olan", hem başkalarına hem de kendilerine karşı dürüst olan otantik liderlere ihtiyaç duymaya başlanmıştır (Kesken ve Ayyıldız, 2008; 734735). Bu bakış açısıyla incelendiğinde her ne kadar araştırma kapsamında incelenen tüm liderlerin iyi oluş üzerinde olumlu etkisi olsa da otantik liderliğin ön plana çıkması şaşırtıcı değildir.

Otantik liderlerin ilişkilerinde şeffaf olması, güvensizlik ve art niyetli davranışların; içselleştirilmiş ahlak anlayışının bulunması, doğrudan saldırgan davranış sergilenmesinin; karar almada bilginin dengeli değerlendirilmesi ile birlikte içselleştirilmiş ahlak anlayışının, adaletsizliğin ortaya çıkmasını; sergiledikleri davranışların farkında olmaları, aşırı olumsuz geri bildirim vermelerini ve çalışanlarını güçlendirmeye önem vermeleri çalışanların önemsenmeme hissiyatını engellediği düşünülmektedir. Yücel ve Kılıç’ın (2017) çalışması da, otantik liderlik algısı yüksek olan çalışanların örgütsel güven algılarının da yüksek olduğunu gözlemlemesi çalışma bulgularıyla benzerlik göstermiştir.

Araştırmada ayrıca çalışanların en fazla bekledikleri "mutlu eden yönetici davranışları" irdelenmiştir. Araştırma bulgularına göre daha fazla çözüm odaklı, güvenilir ve pozitif iletişim kuran yöneticilerin talep edildiği saptanmıştır. En fazla iletişim yetersizliğiyle karşılaşan katılımcıların yöneticinin de pozitif iletişime önem vermesini istemesi sonuçların katılımcıların yaşamış oldukları problemlerle kısmen benzer nitelikte olduğunu göstermektedir.

Son olarak beklenen liderlik tarzları ile katılımcıların cinsiyetleri, yaşları, eğitim düzeyleri, sektörleri, gelirleri ve bulundukları kurumda çalışma süreleri karşılaştırılmış ve anlamlı bir ilişki olmadığını saptanmıştır. Bu sonuç artık çalışanların beklentilerinin ortak olduğunu göstermektedir.

Bu çalışmanın bulguları işletmelerde en fazla yaşanan problemleri, çalışanların beklentileri, farkılıaşan koşullara göre talep edilen liderlik tarzını ve bu liderlik tarzının küresel bir özellik taşıdığını bulgulamıştır. Bu doğrultuda yöneticilerin çalışanlarla olan ilişkisinde özellikle iletişim yetersizliği, adaletsizlik, çalışanları önemsememe ve aşırı rol/ iş yükü gibi problemlere özellikle dikkat etmesi ve bu sorunların çözümüne yönelik hareket etmesi önerilmektedir. Yöneticilerin sonuç ve çözüm odaklı, güvenilir ve pozitif iletişim kuran bir yönetici olma yolunda kendisini geliştirmesi gerektiği düşünülmektedir. Ek olarak otantik liderlik tarzının yöneticiler tarafından öğrenilmesi ve birçok farklı koşulda etkili olan bu liderlik tarzının benimsenmesi gerektiği tavsiye edilmektedir. Öte yandan bu araştırmanın sadece dört liderlik tarzını ele aldığı ve sadece çalışanlar ile görüşüldüğü dikkate alındığında, araştırmacılara; literatürün genişletilmesi amacıyla çalışmanın farklı liderlik tarzlarının da eklenerek tekrarlanması ve yöneticilerin de çalışanlarla ilgili görüşlerinin alınması önerilmektedir.

\section{KAYNAKÇA}

Akbolat, M , Işık, O.ve Yılmaz, A . (2015). Dönüşümcü liderlik davranışının motivasyon ve duygusal bağlılığa etkisi . Uluslararası İktisadi ve İdari İncelemeler Dergisi, (11).

Alparslan, A,M, Yastıoğlu, S. ve Taş, M.A, (2019). Mutlu Eden Yöneticiler, Pozitif Psikoloji Bağlamında Araştırmalar ve Öneriler, Atlas Akademik Basım Yayın Dağıtım, Ankara.

Alper Ay, F . ve Keleş, K . (2017). Etkileşimci ve dönüşümcü liderlik tarzlarının işten ayrılma niyeti ve iş performansı üzerinde etkisi . Gümüşhane Üniversitesi Sağlık Bilimleri Dergisi , 6 (4) , 193-203. 
Arnold, K. A., Turner, N., Barling, J., Kelloway, E. K., \&McKee, M. C. (2007). Transformational leadership and psychological well-being: the mediating role of meaningful work. Journal of occupational health psychology, 12(3), 193.

Atar, A. ve Konaklıoğlu, E. (2018). Konaklama işletmelerindeki liderlik davranış türlerinin örgütsel sessizlik, örgütsel sinizm ve psikolojik iyi oluşa etkisi: Türkiye ve İtalya üzerine bir çalışma, Türk Turizm Araştırmaları Dergisi, Cilt.2, Sayı.3, ss.45-65.

Ayan, A., Ünsar, A. S., \& Oğuzhan, A. (2016). Liderlik tarzlarının örgütsel sessizlik ve tükenmişlik düzeyi üzerine etkisi: Bir alan araştırması. Celal Bayar Üniversitesi Sosyal Bilimler Dergisi, 14(2), 507-538.

Ayça, D. (2016).Otantik Liderlik davranışının iş tatmini ve örgütsel bağlıığa etkisinin incelenmesi ve otel işletmelerinde bir araştırma, Haliç Üniversitesi Sosyal Bilimler Enstitüsü İşletme Anabilim Dalı, Doktora Tezi, İstanbul.

Baykal, E , Zehir, C. ve Köle, M . (2018). Hizmetkar liderlik firma performansı ilişkisinde örgütsel özdeşleşmenin aracı etkisi .Akademik Hassasiyetler , 5 (9) , 111133 .

Baykal, E . (2017). Otantik liderlik ve pozitif çıktıları: pozitif örgütsel davranış bakış açısı :Uluslararası İktisadi ve İdari Bilimler Dergisi , 3 (3) , $42-64$.

Bekmezci, M., ve Yıldız, B. (2019). Babacan liderlik psikolojik sahipliği nasıl etkilemektedir? Kolektif şükranın aracı rolü, İstanbul Ticaret Üniversitesi Sosyal Bilimler Dergisi, 18 (35), 309-324.

Cömert, M. (2004). Dönüşümcü liderlik. XIII. Ulusal Eğitim Bilimleri Kurultayı, 6-9.

Çekmecelioğlu, H. G. (2014). Göreve ve insana yönelik liderlik tarzlarının örgütsel bağlılık, iş performansı ve işten ayrılma niyeti üzerindeki etkileri.

derKinderen, S.,Valk, A., Khapova, S. N., \&Tims, M. (2020). facilitating eudaimonic well-being in mental health care organizations: The role of servant leadership and workplace civility climate. International Journal of Environmental Research and Public Health, 17(4), 1173.

Eren, M. ve Títizoğlu, Ö . (2014). Dönüşümcü ve etkileşimci liderlik tarzlarının örgütsel özdeşleşme ve iş tatmini üzerindeki etkileri . Sosyal Ekonomik Araştırmalar Dergisi , 14 (27) , 275-303.

Erkutlu, H., \&Chafra, J. (2017). Authentic leadership and organizational job embeddedness in higher education. Hacettepe Üniversitesi Ĕgitim Fakültesi Dergisi (HU Journal of Education), 32(2), 413-426.

Gerçek, M . (2018). Yöneticilerin babacan (paternalist) liderlik davranışlarının psikolojik sözleşme bağlamındaki beklentileri üzerindeki etkilerine yönelik bir çalışma . Eskişehir Osmangazi Üniversitesi İktisadi ve İdari Bilimler Dergisi , 13 (2) , 101-118.

Günaydın, S , Ürü Sanı, F , Atan Tarlacı. ve Ö , Yozgat, U . (2016). Hizmetkâr liderliğin pozitif örgütsel davranış değişkenleri ile ilişkisi üzerine bir araştırma .Elektronik Mesleki Gelişim ve Araştırmalar Dergisi , 4 (1) , 0-0.

Hennessey, J. T. (1998). Reinventing government: does leadership make the difference? public administration review, 58 (6): $522-528$.

Hırlak, B. ve Taşlıyan, M . (2017). Otantik liderliğin insan kaynakları yönetimi uygulamaları, işten ayrılma niyeti ve çalışan performansı üzerine etkisi: Hastanelerde Bir Uygulama .Assam Uluslararası Hakemli Dergi , 4 (7) , 34-54 .

Ilies, R., Morgeson, F. P., \&Nahrgang, J. D. (2005). Authentic leadership and eudaemonic well-being: Understanding leader-follower outcomes. The leadership quarterly, 16(3), 373-394.

Jackson, T. (2016). Paternalistic leadership: The missing link in cross-cultural leaderships tudies? International Journal of Cross Cultural Management. 16(1):3$7 .$.

Kahveci, H., ve Aypay, A. (2012). Hizmetkâr örgütlerde örgütsel liderlik değerlendirme ölçeği: türk kültürüne uyarlama, dil geçerliği ve faktör yapısının incelenmesi. Eskişehir Osmangazi Üniversitesi Sosyal Bilimler Dergisi, 13(1), 19-42.

Karacaoğlu, K. ve Satır, F . (2019). Çalışanların otantik ve hizmetkâr liderlik algılamalarının, performansları üzerindeki etkileri: Kayseri Organize Sanayi Bölgesinde bir işletme uygulaması. Erciyes Üniversitesi Iktisadi ve Idari Bilimler Fakültesi Dergisi , (53) , 87-111 .

Kesken, J. ve Ayyıldız, N. A. (2008). Liderlik yaklaşımlarında yeni perspektifler: pozitif ve otantik liderlik. Ege Akademik Bakış Dergisi, 8(2), 729-754.

Kılınç, U , Akdemir, M . (2019). Otel işletmelerinde otantik liderlik algısı ve işyeri mutluluğu: Ankara ilinde bir uygulama . Süleyman Demirel Üniversitesi İktisadi ve İdari Bilimler Fakültesi Dergisi , 24 (4) , 793-811.

KOÇAK, R. D., \& Özüdoğru, H. (2012). Yöneticilerin liderlik özelliklerinin çalışanların motivasyonu ve performansı üzerindeki etkileri: Kamu ve özel hastanelerinde bir uygulama. Gazi Üniversitesi Ticaret ve Turizm Eğitim Fakültesi Dergisi, (1), 76-88.

Koçel, T, (2014). İşletme Yöneticiliği, Beta Yayınevi, Ankara.

Koçel, T. (2018). İşletme Yöneticiliği, 17. Baskı. Beta Yayınevi, Ankara.

Küçük, K. ve Yavuz, E . (2018). Hizmetkar liderlik: Gandhi örneği. Uluslararası Liderlik Çalışmaları Dergisi: Kuram ve Uygulama , 1 (2) , 81-93.

Leli, L. (1999). The relationship between planning, transformational leadership and transactional management (Basılmamış Doktora Tezi). Illinois Üniversitesi.

Liderlik Tarzları,Https://Www.Biymed.Com/Makaleler/Kisisel-Gelisim/Liderlik/Liderlik-Tarzlari-Ve-Liderlik-Turleri-Etkili-Liderlik-Ozellikleri.HtmI (Erişim.Tarihi: 23.08.2020)

Liu, J., Siu, O. L., \&Shi, K. (2010). Transformational leadership and employee well-being: The mediating role of trust in the leader and self-efficacy. Applied Psychology, 59(3), 454-479.

Maula-Bakhsh, R., \&Raziq, A. (2016). Development of conceptual link between servant leadership \& employee subjective well-being. Journal of Applied and Emerging Sciences, 4(2), pp157-168.

Maula-Bakhsh, R., \&Raziq, A. (2018). Relationship between servant leadership and subjective well-being: Evidence from manufacturing and services based SMEs in Pakistan. Journal of Management Sciences, 5(1), 62-85.

Nal, M.ve Tarım, M . (2017). Sağıık yöneticilerinin paternalist liderlik davranışlarının çalışanların iş doyumu üzerine etkisi . Artvin Çoruh Üniversitesi Uluslararası Sosyal Bilimler Dergisi, 3 (2), 117-141.

Nelson, K., Boudrias, J. S., Brunet, L., Morin, D., De Civita, M., Savoie, A., \&Alderson, M. (2014). Authentic leadership and psychological well-being at work of nurses: The mediating role of work climate at the individual level of analysis. Burnout Research, 1(2), 90-101.

Nie, D., \&Lämsä, A. M. (2018). Chinese immigrants' occupational well-being in Finland: the role of paternalistic leadership. Leadership\&Organization Development Journal, Vol. 39, No. 3, pp. 340-352

Nielsen, K., \&Daniels, K. (2012). Does shared and differentiated transformational leadership predict followers' working conditions and well-being?. The Leadership Quarterly, 23(3), 383-397.

ÖCAL, H., \& BARIN, N. (2016). Örgütlerde otantik liderlik davranışının işe yabancılaşma ile ilişkisi: Bursa ili dericilik sektöründe bir araştırma. Is, Guc: The Journal of Industrial Relations\& Human Resources, 18(2), 63-94.

Rahimnia, F., \&Sharifirad, M. S. (2015). Authentic leadership and employee well-being: The mediating role of attachment insecurity. Journal of Business Ethics, 132(2), 363-377.

Ruíz, P., Martínez, R. ve Rodrigo, J. (2010). İşletme organizasyonlarında organizasyon içi sosyal sermaye. Öncül olarak hizmetkâr liderliğe odaklanan teorik bir model. RamonLlull Uygulamalı Etik Dergisi , (1), 43-59. 
Shea, C. M. (1999). The Effect of Leadership Style on performance Improvement on a manufacturing task, Journal of Business, 72 (3): $407-422$

ULUKÖY, M., KILIÇ, R., \& BOZKAYA, E. (2014). Hiyerarşik yapısı yüksek olan kurumlarda liderlik yaklaşımlarının çalışanların motivasyonu üzerine etkisi. Suleyman Demirel UniversityJournal of Faculty of Economics\&AdministrativeSciences, 19(1).

Usta, M. ve Ünsal, Y . (2018). Okullarda algılanan hizmetkâr liderlik düzeyinin incelenmesi . Sakarya UniversityJournal Of Education , 8 (4) , $168-184$.

Yammarino, F. ve Bass, B. M. (1990). Transformationa leadership and multiple levels of leadership, Human Relations, 43 (1990): $975-995$.

Yeşiltaş, M., Kanten, P., ve Sormaz, Ü. (2013). Otantik liderlik tarzının prososyal hizmet davranışları üzerindeki etkisi: Konaklama işletmelerine yönelik bir uygulama. IstanbulUniversityJournal of the School of Business Administration, 42(2).

Yılmaz, P. (2019). Öğretmen algılarına göre okul müdürlerinin dönüşümcü liderlik davranışları ile örgütsel iletişim arasındaki ilişkinin incelenmesi (Yüksek Lisans Tezi). İstanbul Sabahattin Zaim Üniversitesi Sosyal Bilimler Enstitüsü.

Yücel İ. ve Kılıç E.(2018). "Otantik liderlik ve örgütsel güven - Erzincan Üniversitesi’nde bir uygulama", Anadolu Üniversitesi Sosyal Bilimler Dergisi, 18,.81-.

EK-1

Senaryo 1- Adaletsizlik: A kişisi bir şirkette çalışırken aynı zamanda bir üniversitede yüksek lisans yapıyor. Çalıştığı birimde tıpkı onun gibi çalışırken eğitim almasına izin verilen birçok çalışan vardır. Diğer personeller derse giderken koşulsuz izin verilirken $A$ kişisinden fazla mesai yapması istenmektedir. $A$ kişisinin yöneticisiyle farklı Dünya görüşlerine sahip olduğu bilinmektedir. Halbuki A kişisi eğitiminden dolayı yapması gereken kişi bugüne kadar aksatmamıştır.

Senaryo 2- Güvensizlik: A kişisi yöneticisine çalışma arkadaşı C ile ilgili yaşadığı bir sorunu dile getiriyor ve amiri de ona hak vererek $\mathrm{C}$ ile konuşacağını söylüyor. A kişisi, sorun yaşadığı C kişisi ile tartışma noktasına geldiği bir gün yönetici $B$ bu tartışmaya sessiz kalıyor. Bunun yanında $C$ kişisi, yöneticisinin kendisini haklı bulduğunu ifade ediyor. Bunu öğrenen A kişisi hayal kırıklığına uğruyor ve artık sabahları yöneticisi $B^{\prime} y i$ kendi arabasıyla işe götürmeyi istemiyor.

Senaryo 3- Art Niyetli Davranışlar: A kişisi yeni girdiği işte kendini üstlerine göstermek için çok çabalıyor. A’nın yönetici B ise mesleğe yıllarını vermesine rağmen beklediği takdiri toplayamıyor ve arzuladığı genel müdürlük kadrosuna ulaşamıyor. A kişisinin ileride genel müdür kapasitesinin olduğu konuşuluyor. Bir gün işi ile ilgili sorun yaşayan A’ya B “Üst yönetimdeki dostların sorununu çözmedi mi ?” diye bir soru soruyor. Sonraki günlerde A’nın kulağına işe torpille girdiğine dair söylemler geliyor. Bu söylemler çıktıktan sonra insanların kendinden uzaklaştığını hissediyor.

Senaryo 4- Aşırı Nezaret/ Hiyerarşik Tavır: A yaptığı iş ile ilgili kısmen deneyimli ve performansı da iş arkadaşlarına göre ortalama ve bazen daha iyi bir çalışandır. A'nın performansına rağmen yöneticisi B neyin nasıl yapılacağına dair direktifler vermekte, söylediğinin yapılması için baskıcı bir tutum sergilemektedir. Ayrıca gereğinden fazla A'nın yanına gelerek onu kontrol etmektedir. A'yı en çok rahatsız eden konu ise yönetici B'nin sürekli olarak emir veriyormuş gibi konuşmasıdır.

Senaryo 5- Aşırı Rol/ İş Yükü: Yönetici B, A kişisine sorumlu olduğu görevlerin dışında yeni görevler vermiştir. A kişisi ilk defa bu kadar çok iş yükü altında hissetmektedir. Hatta bu görevler son tarihi çok yakın olan görevlerdir. A kişisi bu görevleri hakkıyla yerine getiremeyeceğini düşünmektedir.

Senaryo 6- Olumsuz Geri Bildirim: A kişisi işlerini özenli bir şekilde yapmaya çalışan bir kişidir. Yapmış olduğu işleri yöneticisine beğendirebilmek için uzun saatler çalışmaktadır çünkü yönetici B zor beğenen bir kişidir. Ayrıca olumsuz bir durumda işi yapanı ağır bir biçimde eleştirir. Yönetici B özellikle müşterilerle sorun yaşadığında bunun acısını çalışanlarından çıkartır.

Senaryo 7- Doğrudan Saldırgan Davranışlar: İş yerinin kurallarına uymaya çalışan A kişisi bir gün iş yerinde bir hata yapmıştır. Bu hatayı fark eden Yönetici B agresif ve kısmen aşağılayıcı tavırlarıyla çalışanını azarlamıştır. Tekrarlanması durumunda gerekenin yapılacağını belirten yönetici, çalışan A'nın tatil yapacağı hafta sonuna ek bir görev yazmıştır.

Senaryo 8- Kendini Önemseme, Benlik Yönelimi: A kişisi çalıştığı iş yerinde birimindeki yönetici B'den şikayetçidir. Çünkü yönetici B yoğun dönemlerde hem çalışanlarına yardımcı olmayan hem de kendisini ön plana çıkarmaya çalışan bir kişidir. Yönetici $B$, kurumun amaçlarından öte kendi terfisi için gereken işleri yapmaktadır. Bu sebeple başkalarının yaptığı işten memnun olmamakta kendisinin yaptığı işlerin daha iyi olduğuna dair algı oluşturmaktadır.

Senaryo 9- Çalışanları Önemsememe: Yönetici B kararlarını verirken geçmiş deneyimlerinden yararlanmaktadır. Ülkesindeki ekonomik koşullar nedeniyle işletme sıkıntılar yaşamaktadır. Yönetici B bu durum için kendince çözümler üretmeye çalışmaktadır. A kişisinin çeşitli iyileştirme geliştirme önerileri bulunmasına rağmen yönetici B bu önerilere kulak bile asmamaktadır. İşletme içerisinde yürürken bile, A kişisi de dahil olmak üzere çalışanlarını görmezden gelmektedir.

Senaryo 10- İletișim Yetersizliği: Bir firmada kalite çalışmaları kapsamında farklı departmanlardan gelen çalışanların oluşturduğu takıma Yönetici olarak B kişisi atanmıştır. Takımda çalışan A kişisi takımdaki diğer çalışanlar gibi tedirgindir. Ancak yönetici B, çalışanların ilk defa birbirleriyle çalışacak olmalarından kaynaklanan tedirginliği kendilerine olan güvensizlik olarak hissetmektedir. Kendine olan güvensizliği zayıflık olarak yargılayan yönetici çalışanlarıyla iletişimi en az düz 